\title{
Development of Interactive Digital Book Learning Media Based on Realistic Mathematics Approach to Improve Students' Spatial Ability at SMP It Ikhwanul Muslimin
}

\author{
Cici Puspaningrum Edi Syahputra Edy Surya \\ Mathematics Education Study Program, Medan State University, Indonesia
}

\begin{abstract}
This study aims to: 1) develop an interactive book learning media based on a realistic mathematical approach to the valid, practical, and effective flat-sided geometry material (cubes and blocks) so as to improve students' mathematical spatial abilities; 2) improve students' mathematical spatial abilities by using interactive book media based on a realistic mathematical approach to the material of flat side shapes (cubes and blocks). This research is a development research. The development model used in this study is the ADDIE model with 15 students in class VIII-1 and 15 students in class VIII-2 at SMP IT Ikhwanul Muslimin as the research subject. The validity of the learning media developed was reviewed from the analysis of the results of the validity of the learning media by the validators with a total average value of 3.73 ("Valid" category). Meanwhile, the practicality of learning media is seen from the observation score of the implementation of learning in the second trial, which is 3.73 (category "Well Implemented"). The effectiveness of learning media in terms of four aspects, namely classical completeness, student activity observation scores, and student responses. The classical mastery of the students' mathematical spatial ability in the second trial was $86.67 \%$ (13 students). The average percentage of students' achievement in the ideal time of activity in the second trial for three meetings was $24.07 \%, 28.70 \%, 26.39 \%, 11.11 \%, 6.48 \%$, and $3.24 \%$. The average student response in the second trial was 3.74 (category "Interested").
\end{abstract}

Keywords:Interactive Digital Book, Realistic Mathematics Approach, Spatial Ability, Development of Mathematics Learning Media, Cubes and Blocks.

DOI: $10.7176 / \mathrm{JEP} / 12-21-02$

Publication date:July $31^{\text {st }} 2021$

\section{PRELIMINARY}

Mathematics is one of the basic sciences that has a very important influence in life, because it can prepare and develop students' ability to think logically, kindly, and appropriately to solve problems that occur in their daily lives (Noviani, Syahputra, and Murad, 2007). 2017). Based on the results of the TIMSS study conducted every 4 years, in 2003 Indonesia was ranked 35th out of 46 participating countries with an average score of 411, while the international average score was 467. In 2007, Indonesia was ranked 36th out of 49 countries. participants with an average score of 397 while the average international score was 500. In 2011, Indonesia was ranked 38th out of 42 participating countries with an average score of 386, while the international average score was 500. And in 2015 Indonesia was ranked 44th out of 49 participating countries with an average score of 397 , while the international score was 500 (Hadi and Novaliyosi, 2019: 563). Asih (2018: 2) which states that geometry is one of the branches of mathematics that must be mastered by students because geometry supports many topics in order to solve problems in mathematics that will be useful in the process of solving mathematical problems.

Boakes (Susanti \& Rosyidi, 2013) argues that spatial visualization is the most important part in geometric thinking, because visualization is the ability to imagine, rotate, select or reverse two or three-dimensional objects. In Utami's research (2020: 131) stated that the mathematical spatial ability of class X students at one private Madrasah Aliyah in Singkawang is still low. There are two forms of errors in solving mathematical spatial ability problems, namely conceptual errors and operating/procedural errors. Some of the findings that occurred above are not much different from the conditions found in the IT Ikhwanul Muslimin Middle School. To see more about this problem, The researcher conducted an initial test on the spatial ability of the Ikhwanul Muslimin IT Junior High School students in class VIII-1 on the subject matter of flat-sided space. Of the 26 students who took the test, it was found that 5 students $(19.23 \%$ ) had completed and 21 students (80.97\%) did not. With the percentage of each indicator with a percentage value of $59.29 \%$ students are low on the relation indicator, $65 \%$ of students are on the visualization indicator, $56.43 \%$ of students are low on the perception indicator, $47.14 \%$ of students are very low on the mental rotation indicator, and $70 \%$ of students are on the orientation indicator.

Therefore, we need an appropriate learning activity to improve students' spatial abilities, including using interactive digital book learning media to be able to describe geometric shapes in real contexts. So that students will be easier to understand, not just understanding routine problems. Likewise, it is stated in the research of Arifin, Pujiastuti, and Sudiana (2020: 71) that learning media can improve mathematical spatial abilities caused by several things, namely: (1) By using this learning media students can manipulate real objects, namely manipulating objects that are physical and can be a learning experience for students; (2) the learning steps contained in the guidebook 
also use the STEM approach so that learning is linked between each STEM element so that it becomes more meaningful; and (3) the learning media developed in their activities do not provide information about the material directly, but require students to seek knowledge by exploring their learning media and building students' knowledge independently. The use of learning resources and learning media is a strategy in learning. This is in line with Surya's research (2010) which states that learning mathematics must be made with fun and exciting strategies so that learning objectives can be achieved. and (3) the learning media developed in their activities do not provide information about the material directly, but require students to seek knowledge by exploring their learning media and building students' knowledge independently. The use of learning resources and learning media is a strategy in learning. This is in line with Surya's research (2010) which states that learning mathematics must be made with fun and exciting strategies so that learning objectives can be achieved. and (3) the learning media developed in their activities do not provide information about the material directly, but require students to seek knowledge by exploring their learning media and building students' knowledge independently. The use of learning resources and learning media is a strategy in learning. This is in line with Surya's research (2010) which states that learning mathematics must be made with fun and exciting strategies so that learning objectives can be achieved. The use of learning resources and learning media is a strategy in learning. This is in line with Surya's research (2010) which states that learning mathematics must be made with fun and exciting strategies so that learning objectives can be achieved. The use of learning resources and learning media is a strategy in learning. This is in line with Surya's research (2010) which states that learning mathematics must be made with fun and exciting strategies so that learning objectives can be achieved.

Hafizd and Masriyah (2020: 135) that the learning media developed is of good quality because it meets the valid, practical, and effective criteria. Valid because the learning media is declared valid by the validator, practical because the teacher's activity using learning media in the classroom is very good, and student activity is active, while effective because the student's response to learning is positive, student learning mastery is achieved, and there is an increase in student understanding. In this study, researchers used interactive digital books as learning media for teaching and learning activities on the grounds that interactive digital books are learning media that are able to present audiovisual messages clearly to students and material that is real,

The other solution so that students' spatial abilities can increase is by using a realistic mathematics learning approach. According to Herzamzam and Rahmad (2020: 185) realistic mathematics learning is basically the use of reality and the environment that students understand to facilitate the mathematics learning process, so as to achieve the goals of mathematics education better than in the past. Tasmalina \& Prabowo (2018) which states that a realistic mathematics approach provides opportunities for students to be more active in solving learning problems and have a positive attitude towards mathematics subjects.

Based on the description above, the authors are interested in conducting research related to learning media, realistic mathematics learning approaches, and students' spatial abilities entitled "Development of Interactive Digital Book Learning Media Based on Realistic Mathematics Approaches to Improve Students' Spatial Ability at SMP IT Ikhwanul Muslimin".

\section{METHOD}

This research was conducted at the IT Ikhwanul Muslimin Middle School in Medan in the even semester of the 2020/2021 academic year. The subjects in this study were students of class VIII-1 and VIII-2 SMP IT Ikhwanul Muslimin Medan. The object in this study is an interactive digital book learning media based on a realistic mathematical approach to the material for building flat sides (cubes and blocks). This type of research is Research and Development using the ADDIE model.

\section{Data collection}

The data collection instrument consisted of a validation sheet that was used to obtain data on the quality of learning devices based on the assessment of experts. Some of the validation sheets used include: validation sheets for learning media experts; validation sheet for Learning Implementation Plan (RPP); validation sheet for Student Worksheet (LKPD). Then for the practicality questionnaire filled out by students and students' spatial ability tests. The data obtained from the results of the spatial ability test were analyzed to determine the increase in students' spatial abilities. The data were obtained from the results of the pre-test and post-test of students' spatial abilities. To calculate the increase in students' spatial ability, the n-gain value is determined first. In calculating n-gain, the formula is used (Lestari and Yudhanegara, 2015: 235):

Normalized gain $=\frac{S_{\text {post }}-S_{\text {pre }}}{S_{\text {max }}-S_{\text {pre }}}$

Information:

$N-$ Gain $=$ normalized gain score

$S_{\text {post }}=$ final test score

$S_{\text {pre }}=$ preliminary test scores 
maximum score $=S_{\max }$

Table 8

N-Gain Score Criteria

\begin{tabular}{cc}
\hline Gain Score (g) & Criteria \\
\hline $\mathrm{g} 0.3 \leq$ & Low \\
\hline $0.3<\mathrm{g} 0.7 \leq$ & Medium \\
\hline $\mathrm{g}>0.7$ & High \\
\hline
\end{tabular}

Source: (Hake, 1999)

\section{RESULTS AND DISCUSSION}

\section{Validity of Interactive Digital Book Learning Media}

Table 9

Summary of Validation Results of Interactive Learning Media and Validated Learning Instruments

\begin{tabular}{llc}
\hline \multicolumn{1}{c}{ Validated Instrument } & Score & Category \\
\hline Learning Media & 3.73 & Valid \\
\hline Lesson plan (RPP) & 3.74 & Valid \\
\hline Student Worksheet (LKPD) & 3.84 & Valid \\
\hline Mathematical spatial ability preliminary test & 3.85 & Valid \\
\hline Mathematical spatial ability final test & 3.89 & Valid
\end{tabular}

\section{The Practicality of Interactive Digital Book Learning Media}

The practicality of developing interactive digital book learning media has met the practical criteria in terms of the results of the assessment of the experts (validators), all validators stated that the interactive digital book learning media developed was feasible to use with a little revision. Then, observe the implementation of learning using interactive digital book learning media in table 10 below:

Table 10

Summary of Observation Results of Learning Implementation

\begin{tabular}{cccccc} 
& \multicolumn{3}{c}{ Trial I } & \multicolumn{3}{c}{ Trial II } \\
\cline { 2 - 6 } & PI & PII & PI & PII & PIII \\
\hline Score & 2.80 & 2.93 & 3.60 & 3.73 & 3.87 \\
\hline Average & \multicolumn{3}{c}{2.87} & & 3.73 \\
\hline Category & Implemented Poorly & & Well done
\end{tabular}

Based on the table, it can be seen that the learning implementation observation score did not meet the practicality criteria in the first trial, namely with a score of 2.80 at the first meeting, a score of 2.93 at the second meeting, and an average of 2.87 (category "Not Well Implemented". "). While in the second trial, a score of 3.60 was obtained at the first meeting, 3.73 at the second meeting, and 3.87 at the third meeting. The average result of the observation of the implementation of learning in the second trial was 3.73 with the category "Well Implemented".

\section{The Effectiveness of Interactive Digital Book Learning Media}

Mathematical Spatial Ability Test Achievement

Based on the results of the test analysis in the first and second trials, it was found that the students' spatial abilities had met the classical completeness criteria. The description of the results of students' spatial abilities is shown in table 11 below:

Table 11

Mathematical Spatial Ability Test Achievement Summary

\begin{tabular}{ccc}
\hline \multirow{2}{*}{ Trials } & \multicolumn{2}{c}{ Achievement on } \\
\cline { 2 - 3 } & Pre-test & Final Test \\
\hline I & $20 \%$ & $40 \%$ \\
\hline II & $33.33 \%$ & $86.67 \%$ \\
\hline
\end{tabular}

The achievement of the final test of students' mathematical spatial abilities in the first trial was $40 \%$ with a total of 6 students declared complete. So, it can be concluded that in the first trial the application of the developed interactive digital book learning media did not meet the criteria for achieving classical completeness $(>80 \%)$. However, in the second trial, the achievement of the final test of mathematical spatial ability of students has met the specified criteria, which is $86.67 \%$ with a total of 13 students declared complete. Thus, it can be said that the interactive digital book learning media has met the effectiveness criteria in the aspect of achieving students' mathematical spatial abilities. 
Student Activities

Based on the results of the first trial, it can be concluded that all student activities meet the ideal percentage of time set. The summary can be seen in table 12 below:

Table 12

Summary of Ideal Time Percentage of Student Activities in Trial I

\begin{tabular}{|c|c|c|c|c|c|}
\hline \multirow[b]{2}{*}{ Observation Aspect } & \multicolumn{2}{|c|}{ Meeting } & \multirow{2}{*}{$\begin{array}{l}\text { Average } \\
\quad(\%)\end{array}$} & \multirow{2}{*}{$\begin{array}{c}\text { Time } \\
\text { Ideal }(\%)\end{array}$} & \multirow[b]{2}{*}{ Tolerance } \\
\hline & I & II & & & \\
\hline $\begin{array}{l}\text { Paying attention and listening to the } \\
\text { explanation of the teacher or friend }\end{array}$ & 25 & 22.22 & 23.61 & 20 & $15 \%$ PWI $25 \% \leq \leq$ \\
\hline $\begin{array}{l}\text { Read and understand problems in learning } \\
\text { media or LKPD }\end{array}$ & 23.61 & 29.17 & 26.39 & 30 & $25 \%$ PWI $35 \% \leq \leq$ \\
\hline Find a solution to a given problem & 29.17 & 25 & 27.08 & 30 & $25 \%$ PWI $35 \% \leq \leq$ \\
\hline Discuss and ask the teacher or friends & 11.11 & 15.28 & 13.19 & 10 & $5 \%$ PWI $15 \% \leq \leq$ \\
\hline Draw conclusions from the material studied & 5.56 & 6.94 & 6.25 & 10 & $5 \%$ PWI $15 \% \leq \leq$ \\
\hline $\begin{array}{l}\text { Doing activities that are not relevant to } \\
\text { learning }\end{array}$ & 5.56 & 1.39 & 3.47 & 0 & $0 \%$ PWI $15 \% \leq \leq$ \\
\hline
\end{tabular}

Based on the analysis of the results of observing student activities in the first trial, it was obtained that the average percentage of achieving the ideal time of student activity for the two meetings in the first trial was $23.61 \%$, $26.39 \%, 27.08 \%, 13.19 \%, 6,25 \%$, and $3.47 \%$. While the results of the second trial, it can be concluded that all student activities meet the set ideal percentage of time. The summary can be seen in table 5 below:

Table 13

Summary of Ideal Time Percentage of Student Activities in Trial II

\begin{tabular}{|c|c|c|c|c|c|c|}
\hline \multirow[b]{2}{*}{ Observation Aspect } & \multicolumn{3}{|c|}{ Meeting } & \multirow{2}{*}{$\begin{array}{l}\text { Average } \\
(\%)\end{array}$} & \multirow{2}{*}{$\begin{array}{c}\text { Time } \\
\text { Ideal }(\%)\end{array}$} & \multirow[b]{2}{*}{ Tolerance } \\
\hline & I & II & III & & & \\
\hline $\begin{array}{l}\text { Paying attention and listening to the } \\
\text { teacher or friend's explanation }\end{array}$ & 25 & 23.61 & 23.61 & 24.07 & 20 & $15 \%$ PWI $25 \% \leq \leq$ \\
\hline $\begin{array}{l}\text { Read and understand problems in } \\
\text { learning media or LKPD }\end{array}$ & 29.17 & 29.17 & 26.39 & 28.24 & 30 & $25 \%$ PWI $35 \% \leq \leq$ \\
\hline Find a solution to a given problem & 26.39 & 25 & 27.78 & 26.39 & 30 & $25 \%$ PWI $35 \% \leq \leq$ \\
\hline $\begin{array}{l}\text { Discuss and ask the teacher or } \\
\text { friends }\end{array}$ & 8.33 & 12.5 & 12.50 & 11.11 & 10 & $5 \%$ PWI $15 \% \leq \leq$ \\
\hline $\begin{array}{l}\text { Draw conclusions from the } \\
\text { material studied }\end{array}$ & 5.56 & 6.94 & 6.94 & 6.48 & 10 & $5 \%$ PWI $15 \% \leq \leq$ \\
\hline $\begin{array}{l}\text { Doing activities that are not } \\
\text { relevant to learning }\end{array}$ & 5.56 & 1.39 & 2.78 & 3.24 & 0 & $0 \%$ PWI $15 \% \leq \leq$ \\
\hline
\end{tabular}

Based on the table above, in the second trial the average percentage of students' ideal time for three meetings was $24.07 \%, 28.24 \%, 26.39 \%, 11.11 \%, 6.48 \%$, and $3,24 \%$. Based on these data, it can be concluded that all student activities in the second trial also meet the ideal percentage of time set.

Student Response

Based on the analysis of the results of student responses, it was found that in the first and second trials, students were interested in the learning media developed. More clearly, the data is shown in Table 6 below:

Table 14

Summary of Student Response Questionnaire Analysis Results

\begin{tabular}{ccccc}
\hline \multirow{2}{*}{ Respondent } & \multicolumn{2}{c}{ Trial I } & \multicolumn{2}{c}{ Trial II } \\
\cline { 2 - 5 } & Score & Category & Score & Category \\
\hline Student & 3.70 & Interested & 3.74 & Interested \\
\hline
\end{tabular}

This can be seen from the average score of student responses showing interest in learning with the developed learning media. Judging from the score of the student response questionnaire in the first trial of 3.70 with the interested category and in the second trial of 3.74 with the interested category. So it can be concluded that from the student's response to the interactive digital book learning media that was developed effectively.

Spatial Ability Upgrade Peningkatan

Based on the results of the analysis of the students' mathematical spatial ability test in the first and second trials, it showed that there was an increase in the students' mathematical spatial abilities. The scores for increasing students' mathematical spatial abilities in the first and second trials can be seen in table 15 below: 
Table 15

Increasing Students' Mathematical Spatial Ability

\begin{tabular}{cccc}
\hline & Trial I & \multicolumn{2}{c}{ Trial II } \\
\hline Score & Category & Score & Category \\
\hline 0.20 & Low & 0.40 & Medium \\
\hline
\end{tabular}

Based on the average normalized gain, it was found that in the first trial there was an increase in the spatial ability of students with low criteria with a score of 0.20 (N-Gain) and in the second trial there was an increase in scores with moderate criteria with a score of $0.40(0,3<\mathrm{N}$-Gain So it can be concluded that the interactive digital book learning media developed can improve students' mathematical spatial abilities. $\leq 0,3 \leq 0,7$ )

\section{CONCLUSION}

Based on the results of the research that has been done, it can be concluded that: 1) The validation of the interactive digital book learning media developed was in the "Valid" category in terms of the analysis of the results of the validity of the learning media by the validators with a total average value of 3.73. 2) The interactive digital book learning media developed meets the criteria for the practicality of learning media in terms of the analysis of the results of observing the implementation of learning. The score obtained in the first trial was 2.87 (category "Poorly Implemented") and did not meet the criteria for research success. However, after making several revisions, in the second trial the learning implementation observation score increased to 3.73 (category "Well Implemented"). So that the learning media developed successfully meets the criteria for the practicality of learning media. 3) The developed learning media has met the established effectiveness criteria. In the first trial the achievement of students' mathematical spatial abilities was $40 \%$ (6 students) and in the second trial it was $86.67 \%$ (13 students). The average percentage of students' achievement in the ideal time of activity for the two meetings in the first trial was $23.61 \%, 26.39 \%, 27.08 \%, 13.19 \%, 6.25 \%$, and $3.47 \%$. While in the second trial the average percentage of students' ideal time for three meetings was $24.07 \%, 28.70 \%, 26.39 \%, 11.11 \%, 6.48 \%$, and $3.24 \%$. The average student response in trial I was 3.70 (category "Interested") and in trial II was 3.74 (category "Interested"). 4) The increase in students' mathematical spatial ability is also seen in each indicator of mathematical spatial ability. Based on the normalized gain index, $\leq 0,3 \leq 0,7$ )

\section{BIBLIOGRAPHY}

Akker, JVD (2007). An Introduction to Educational Design Research. Proceedings of The Seminar Conducted at The East China Normal University, Shanghai (PR China). November 23-26.

Anggraini, Y, D. (2020). Development of Novelmatic e-Book Learning Media to Improve Understanding of Statistical Concepts. Journal of Trust in Education and Teaching, 1(1): 35-48.

Annisa, A, R., Putra, A., \& Dharmono. (2020). Practicality of Learning Media Anti-Bacterial Power of Sawo Fruit Extract Based on Macromedia Flash. Quantum: Journal of Science Education Innovation, 11(1).

Arifin, AM, \& Pujiastuti, H., Sudiana, R. (2020). Development of STEM Learning Media with Augmented Reality to Improve Students' Mathematical Spatial Ability. Journal of Mathematics Education Research, 7(1): 59-73. Arsyad, A. (2017). Learning Media. Jakarta: PT Raja Grafindo Persada.

Ashyar, R. (2011). Creative Developing Learning Media. Jakarta: Echoes of Persada (GP) Press Jakarta.

Asih, YK (2018). Spatial Visual Ability in Geometry Problem Solving Based on Van Hieles Thinking Stages. Thesis. Surakarta: Muhammadiyah University of Surakarta.

Azriati, S, A., Syahputra, E., \& Sumarno. (2018). Development of Macromedia Flash-Based Mathematics Learning Media to Improve Students' Spatial Ability. Paradikma Journal of Mathematics Education, 11(1): 2502-7204.

Bosnyak, A., \& Nagy-Kondor, R. (2008). The Spatial Ability and Spatial Geometrical Knowledge of University Students Majored In Mathematics. Acta Didactia Universitatis Comenianae, 8:1-25

De Lange, J. (1996). Using and Applying Mathematics in Education. Netherlands: Kluwe Academic Publisher.

Freudenthal, H. (1991). Revisiting Mathematics Education. Dordrechr: Reidel Publishing.

Hadi, S., \& Novaliyosi. (2019). TIMSS (Trends In International Mathematics and Science Study). Proceedings of the National Seminar \& Call For Papers. Master of Mathematics Education Study Program at Siliwangi University. Tasikmalaya, January 19, 2019. ISBN: 978-602-9250-39-8.

Hafizd, M., \& Masriyah. (2020). Development of Android-Based Learning Media for Permutation and Combination Learning. Kreano Journal of Creative-Innovative Mathematics, 11(2): 126-135.

Hake, RR (1999). Analyzing Change/Gain Scores. Woodland Hills: Dept. Of Physics, Indiana University.

Hasratuddin. (2018). Why Should You Learn Maths. Medan: Perc. Edira.

Herzamzam, DA, \& Rahmad, IN (2020). Application of Realistic Mathematics Education (RME) in Elementary Schools. Prima Magistra: Scientific Journal of Education, 1(2): 184-190.

Istifarida, B., Santoso, S., Yusup, Y. 2017. Development of E-Book Problem Based Learning-GIS To Increase 
Spatial Thinking Skills In Class X SMA N 1 Sragen 2016/2017. Geoeco Journal, 3(2): 133- 144.

Lestari, KE, \& Yudhanegara, MR (2015). Mathematics Education Research. Bandung: Refika Aditama.

Maier, PH (1998). Spatial Geometry and Spatial Ability - How to Make Solid Geometry Solid? Annual Conference od Didactic of Mathematics 1996. Osnabrueck: University of Osnanbrueck. 63-75.

Marselina, V., \& Muhtadi, A. (2019). Development of Interactive Mathematics Digital Books on Geometry Materials. Journal of Educational Technology Innovation, 6(2): 196-207.

Masykur, Ag, M., \& Fathani, AH (2017). Mathematical Intelligence: Smart Ways to Train the Brain and Overcome Learning Difficulties. Yogyakarta: Ar-Ruzz Media.

Nasrah., Jasrudin., \& Tawil. (2015). Development of Physics Learning Devices Based on Contextual Teaching and Learning (CTL) Approach to Motivate and Improve Physics Learning Outcomes for Class VIII Students of SMP Negeri 1 Balocci Pangkep. Journal of Physics Education, 5(2): 235-248

Netriwati \& Lena, MS (2017). Mathematics Learning Media. Bandar Lampung: PermataNet.

Nieveen, N. (2007). An Introduction to Educational Design Research. Proceedings of The Seminar Conducted at The East China Normal University, Shanghai (PR China). November 23-26.

Noviani, J., Syahputra, E., and Murad, A., (2017), The Effect of Realistic Mathematical Education (RME) In Improving Primary School Students' Spatial Ability in Subtopic Two Dimension Shape. Journal of Education and Practice, 8(34): 112-126.

Rosida, Faidawati, N., \& Jalmo, T. (2017). The Effectiveness of Using Interactive E-Book Teaching Materials in Developing Students' Critical Thinking Skills. Journal of Learning Physics, 5(1): 2302-0105.

Rozak, A., Darmadi, \& Murtafi'ah, W. (2018). Development of SASA-AURA Learning Media to improve student achievement of SMK Cendekia Madiun for the 2017/2018 Academic Year. Journal of Education and Science, 18(1): 2614-0578.

Sadjiman, AS, Rahardjo, R., Haryono, A., \& Harjito. (2011). Media Education, Understanding, Development, and Utilization. Jakarta: Rajagrafindo Persada.

Setiawan, A. (2017). Study and Learning. Ponorogo: Uwais Inspiration from Indonesia.

Shoimin, A. (2016). 68 Innovative Learning Models in the 2013 Curriculum Yogyakarta: Ar-Ruzz Media.

Sonda, R., Alimuddin, \& Asdar. (2016). Effectiveness of Realistic Mathematics Learning (PMR) Cooperative Setting Type of NHT on Similarity Materials for Class IX Students of SMP Negeri 1 Simbuang. Journal of Mathematical Power,4(1): 1-12.

Sumarli, Nugroho, S, N., \& Yulianti, I. (2018). The Effectiveness of Creative Problem Solving Learning Model with Inquiry Approach to Students' Science Process Skills. Physics Communication, 2(1): 63-69.

Surya, E. (2010). Visual Thinking in Maximizing Mathematics Learning Students can Build National Character. Journal of Educational Research, 10(10): 1-7.

Susanti, L., \& Rosyidi, AH (2013). Origami-Based Learning To Improve Spatial Visualization and Geometry Ability of Junior High School Students. 2(2): 1-8.

Sutikno, S. (2013). Study and Learning. Lombok: Hollistica.

Tasmalina, T., \& Prabowo, P. (2018). The Influence of Learning Video Media on Student Learning Outcomes in Spermatophyta Sub-Material at Nurul Amaliyah Private High School Tanjung Morawa in the 2015/2016 Academic Year. Best Journal (Biology Education, Science and Technology), 1(1): 14-20.

Utami, C. (2020). Student Errors in Solving Mathematical Spatial Ability Problems. Al-Khwarizmi: Journal of Mathematics and Natural Sciences Education, 8(2): 123-132.

Uygan, C., \& Kurtuluş, A. (2016). Effects of teaching activities via Google Sketchup and concrete models on spatial skills of preservice mathematics teachers. Turkish Journal of Computer and Mathematics Education (TURCOMAT), 7(3): 510-510.

Wiarto, G. (2016). Learning Media in Physical Education. Yogyakarta: Laksitas.

Wibowo, Tri Prayitno. 2014. Development of Multimedia Book Electronic Teaching Materials on Life Organization System Materials in Junior High School. Unnes Journal of Biology Education, 3(1). 